\title{
Effects of salinomycin and 17-AAG on proliferation of human gastric cancer cells in vitro
}

\author{
ZUWEN ZHANG $^{1 *}$, JUMEI ZHAO $^{1 *}$, ZHIKUAN MI $^{1 *}$, QIUXIA PANG $^{1}$, AIHONG WANG $^{1}$, \\ MEINI CHEN ${ }^{1}$, XIAOBIN LIU $^{1}$, XIAOLI WEI ${ }^{1}$ and TAO LIU ${ }^{2}$ \\ ${ }^{1}$ Key Laboratory of Cancer Prevention and Control, Yan'an University; ${ }^{2}$ The First Ward of \\ Department of Otolaryngology, The Affiliated Hospital of Yan'an University, Yan'an, Shanxi 716000, P.R. China
}

Received April 12, 2016; Accepted March 16, 2017

DOI: $10.3892 / \mathrm{mmr} .2017 .6735$

\begin{abstract}
The aim of the present study was to investigate the effects and mechanisms of 17-AAG combined with salinomycin treatment on proliferation and apoptosis of the SGC-7901 gastric cancer cell line. An MTT assay was used to detect the proliferation of SGC-7901 cells. Morphological alterations of cells were observed under inverted phase-contrast and fluorescence microscopes. Cell cycle and apoptosis were assessed by flow cytometry analysis. The protein expression of nuclear factor (NF)-кB p65 and Fas-ligand (L) were evaluated by immunocytochemistry. Salinomycin with a concentration range of 1-32 $\mu \mathrm{mol} / 1$ was demonstrated to inhibit growth of SGC-7901 cells effectively, affect the morphology and apoptosis rate of cells, and arrest SGC-7901 cells in S phase. Furthermore, salinomycin significantly increased the protein expression of Fas-L and decreased the protein expression of $\mathrm{NF}-\kappa \mathrm{B}$ p65. The alterations in SGC-7901 cells co-treated with salinomycin and 17-AAG were more significant compared with cells treated with one drug only. In conclusion, the individual use of salinomycin and combined use with 17-AAG may significantly inhibit SGC-7901 gastric cancer cell proliferation and induce cell apoptosis. The potential mechanisms may be associated with upregulation of Fas-L and downregulation of $\mathrm{NF}-\kappa \mathrm{B}$. These results provide a basis for the potential use of salinomycin in gastric cancer treatment.
\end{abstract}

Correspondence to: Professor Jumei Zhao, Key Laboratory of Cancer Prevention and Control, Yan'an University, 580 Shengdi Road, Yan'an, Shanxi 716000, P.R. China

E-mail: jmz2003.stu@163.com

Dr Tao Liu, The First Ward of Department of Otolaryngology, The Affiliated Hospital of Yan'an University, 43 Center Street, Yan'an, Shanxi 716000, P.R. China

E-mail: hxlt002@163.com

${ }^{*}$ Contributed equally

Key words: salinomycin, 17-AAG, Gastric cancer, Fas-L, NF-кB p65

\section{Introduction}

Gastric cancer is one of the most common malignancies worldwide with a mortality rate of $>70 \%$. East Asia, Eastern Europe and South America are considered to be areas with high incidences (1). The incidence of gastric cancer ranks second in China among malignant cancers $(2,3)$. Furthermore, the overall incidence and mortality of gastric cancer is markedly increased in rural areas compared with urban areas, and gradually increases with age $(4,5)$. Although the survival of gastric cancer patients is prolonged by effective treatment, the 5 -year survival rate remains very low ( 20 to 25\%) (6). Radical gastric tumor resection combined with standard chemotherapy cannot remove the tumor completely, which has become a major issue in current cancer therapy (7).

Salinomycin is a type of carboxy-polyether type compound first extracted from the white Streptomyces albus by Japanese researchers in 1974 (8). Salinomycin is capable of neutralizing cations within cells, and exhibits good inhibitory and destructive effects on most gram-positive bacteria and all types of coccidian (9-11). Gupta et al (12) in 2009 revealed that the toxicity of salinomycin on breast cancer stem cells was 100 times that of the chemotherapeutic drug paclitaxel. In previous years, numerous studies have suggested that salinomycin exhibits anti-tumor effects; therefore, it may represent a novel and effective anticancer agent (9,13-19). However, high doses of salinomycin has high neurotoxicity (20). 17-allylamine-17-demathoxygeldanamycin (17-AAG), an inhibitor of heat shock protein (HSP) 90, shares an extremely similar structure with geldanamycin. 17-AAG exhibits a more effective toxicity profile $(21,22)$. The anti-tumor effects of 17-AAG have also been widely recognized (23).

In order to reduce salinomycin dose and the associated toxicity, and to promote its use in cancer therapy, the present study investigated the effects of salinomycin and 17-AAG combined treatment on gastric cancer cells, which have not been previously reported. This study focused on the inhibition of salinomycin on proliferation of the SGC-7901 gastric cancer cell line, and the pro-apoptotic underlying mechanism of salinolycin. The present study aimed to provide a basis for the use of salinomycin in gastric cancer treatment, in addition to experimental evidence for understanding the mechanism underlying the anti-tumor effects of salinomycin. 


\section{Materials and methods}

Reagents and instruments. Salinomycin was purchased from Sigma-Aldrich (Sigma-Aldrich; Merck KGaA, Darmstadt, Germany). 17-AAG and MTT were purchased from Sigma-Aldrich (Merck KGaA). RPMI-1640 medium was purchased from Thermo Fisher Scientific, Inc. (Waltham, MA, USA). Fetal bovine serum (FBS) was purchased from Zhejiang Tianhang Biotechnology Co., Ltd. (Zhejiang, China). Propidium iodide (PI) was purchased from Merck KGAa. Acridine orange (AO) was purchased from Amresco, LLC (Solon, OH, USA). An Annexin-fluorescein isothiocyanate (FITC)/PI Apoptosis kit was purchased from BD Biosciences (Franklin Lakes, NJ, USA). A DAB chromogenic kit, rabbit anti human nuclear factor (NF)-кB p65 polyclonal antibody (A00224) and rabbit anti human Fas-ligand (L) polyclonal antibody (BA0049) were purchased from GenScript Co., Ltd. (Nanjing, China), biotinylated goat anti rabbit IgG secondary antibody and horseradish peroxidase-labeled avidin secondary antibody were purchased from Wuhan Boster Biological Technology, Ltd. (Wuhan, China).

A carbon dioxide incubator was purchased from Sanyo Electric, Co. (Moriguchi, Japan). Fluorescence and inverted microscopes were purchased from Nikon Corporation (Tokyo, Japan). A flow cytometer was purchased from BD Biosciences. A microplate reader was purchased from Bio-Rad Laboratories, Inc. (Hercules, CA, USA).

Cell culture. The SGC-7901 human gastric cancer cell line was purchased from the Digestion Experimental Research Center of Xi'an Jiaotong University (Xi'an, China). Cells were cultured with RPMI 1640 medium supplemented with $10 \% \mathrm{FBS}$ and $100 \mathrm{U} / \mathrm{ml}$ penicillin and streptomycin, and incubated in $5 \% \mathrm{CO}_{2}$ at $37^{\circ} \mathrm{C}$ with $95 \%$ relative humidity.

MTT assay. SCG-7901 cells in the logarithmic phase were seeded into $96-$ well plates at a density of $1 \times 10^{5} / \mathrm{ml}$ with $100 \mu$ RPMI 1640 medium per well. Cells were divided into four groups: Salinomycin treated $(2,4,8,16$ and $32 \mu \mathrm{mol} / \mathrm{l})$; 17-AAG treated $(0.625 \mu \mathrm{mol} / \mathrm{l})$; salinomycin $(4,8$ and 16 $\mu \mathrm{mol} / \mathrm{l})$ combined with $17-\mathrm{AAG}$ treated $(0.625 \mu \mathrm{mol} / \mathrm{l})$; and the control (complete RPMI 1640 medium). The total volume of each well was $100 \mu \mathrm{l}$ and 5 duplicate wells were set for each group. After incubation for 24,48 or $72 \mathrm{~h}$, the supernatant was removed by centrifugation at $300 \mathrm{x}$ g for $5 \mathrm{~min}$ at room temperature, and $20 \mu \mathrm{l}$ MTT was added. After a 4-h incubation, MTT was removed and $150 \mu \mathrm{l}$ dimethyl sulfoxide was added. The optical density at a wavelength of $495 \mathrm{~nm}$ was detected using a microplate reader. The experiment was repeated three times.

Morphology assay. SGC-7901 cell suspension was seeded into 6 -well plates at a density of $2 \times 10^{5}$ per well. After incubation for $24 \mathrm{~h}$, cells were treated with salionmycin $(4,8$ or $16 \mu \mathrm{mol} / \mathrm{l})$, 17-AAG $(0.625 \mu \mathrm{mol} / \mathrm{l})$, or salinomycin $(8 \mu \mathrm{mol} / \mathrm{l})$ combined with 17-AAG $(0.625 \mu \mathrm{mol} / \mathrm{l})$. Untreated cells served as the negative control. After a 48-h incubation, cell morphology was observed under an inverted phase contrast microscope. The above step was repeated three times.
Apoptosis assay. SGC-7901 cells were treated as described above, washed twice with PBS after a 48-h incubation, and then stained in the dark using PI or AO. Cell apoptotic morphology was observed using a fluorescent microscope.

In addition, cells were collected after trypsin digestion, washed twice with PBS, collected in Eppendorf (EP) tubes and stained with Annexin V-FITC and PI for $10 \mathrm{~min}$. The cell apoptotic rate of each group was detected with a flow cytometer.

Cell cycle assay. Cells were seeded into 6-well plates and cultured for $24 \mathrm{~h}$, and then cultured in RPMI 1640 medium supplemented with $0.5 \%$ FBS for synchronization. After a continuous culture for $24 \mathrm{~h}$, cells were treated as for the morphology assay and cultured for $48 \mathrm{~h}$. Cells were digested, collected, fixed in $70 \%$ alcohol for $30 \mathrm{~min}$, centrifuged at $300 \mathrm{x}$ g for $5 \mathrm{~min}$ at room temperature to remove the supernatant, washed with PBS and collected into an EP tube. PI (the working solution concentration was $50 \mu \mathrm{g} / \mathrm{ml}$ ) staining was performed at $4^{\circ} \mathrm{C}$ for $30 \mathrm{~min}$ before a cell cycle assay was performed by flow cytometry.

Immunocytochemistry assay. SGC-7901 cells were treated as those mentioned in the morphology assay, washed with PBS three times after a 48-h incubation, and fixed with $4 \%$ paraformaldehyde for $20 \mathrm{~min}$. Cells were then fixed with neutral balsam after drying, incubated with $0.3 \%$ Triton X-100 for $15 \mathrm{~min}$ at room temperature, and incubated with trypsin at $37^{\circ} \mathrm{C}$ for $30 \mathrm{~min}$ and $\mathrm{H}_{2} \mathrm{O}_{2}$ for 20 min at room temperature after PBS washing. Subsequently, cells were blocked with blocking reagent for $30 \mathrm{~min}$ and incubated with a rabbit anti human NF-KB p65 polyclonal antibody (1:100) or a rabbit anti human Fas-L polyclonal antibody $(1: 100)$ at $4^{\circ} \mathrm{C}$ overnight, followed by PBS washing. Following this, cells were incubated with a biotinylated goat anti rabbit secondary antibody (1:100) for $2 \mathrm{~h}$, washed with TBS, incubated with a horseradish peroxidase-labeled avidin secondary antibody (1:100) for a further $30 \mathrm{~min}$ at room temperature, and washed three times with TBS. DAB was used for color development. Cells were re-stained with hematoxylin, differentiated with hydrochloric acid alcohol, dehydrated with alcohol, cleared with xylene, and mounted with neutral balsam. Cells were imaged under a Nikon E600 microscope and protein expressions were analyzed using NIS-Elements Documentation (Version 3.0.455) (both from Nikon Corporation, Tokyo, Japan). All the antibodies were diluted with PBS. Untreated cells incubated with PBS, instead of the primary antibodies, served as the secondary antibody control.

Statistical analysis. SPSS software version 22.0 (IBM SPSS, Armonk, NY, USA) was used for statistical analysis. All data are presented as the mean \pm standard deviation. Comparison between groups was conducted by one-way analysis of variance, followed by Fisher's least significant difference post hoc test. $\mathrm{P}<0.05$ was considered to indicate a significantly different difference.

\section{Results}

Salinomycin and 17-AAG alter SGC-7901 cell morphology. To determine the effect of salinomycin and 17-AAG on cell 


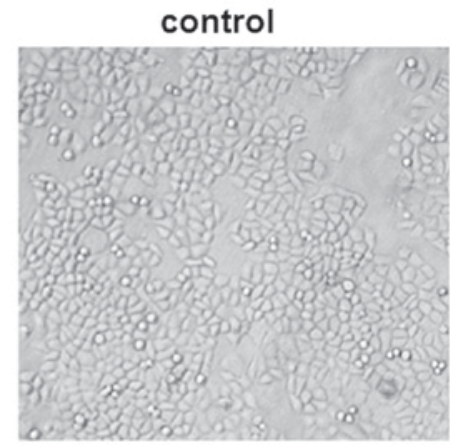

$16 \mu \mathrm{mol} / / \mathrm{s}$ salinomycin

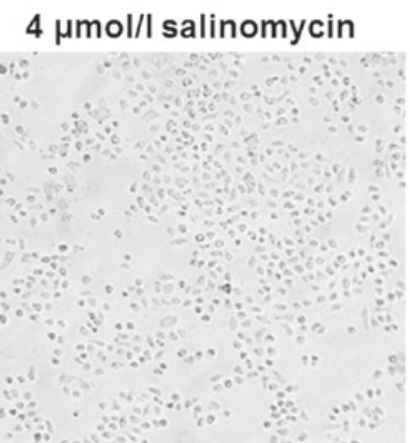

17-AAG

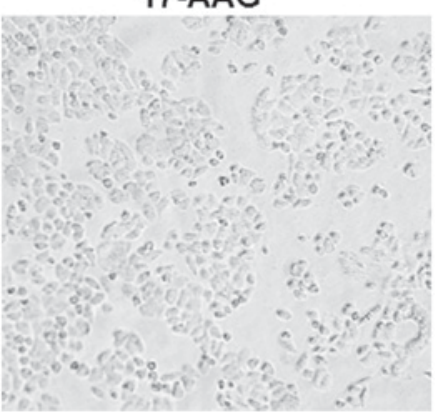

$8 \mu \mathrm{mol} / \mathrm{l}$ salinomycin

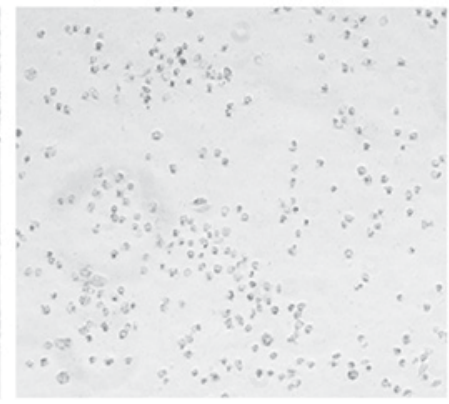

17-AAG \& $8 \mu \mathrm{mol} / \mathrm{l}$ salinomycin
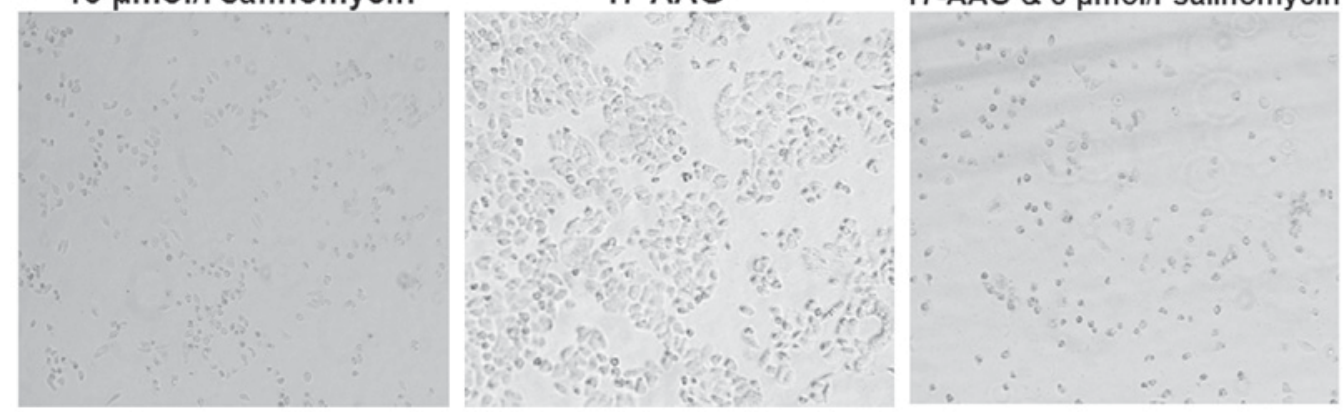

Figure 1. Salinomycin and 17-AAG alters SGC-7901 cell morphology. To evaluate the effects of salinomycin and 17-AAG on SGC-7901 cell morphology, an inverted microscope was used for morphological observation. Cells were untreated (control), treated with salinomycin (4, 8 and 16 $\mu$ mol/l), 17-AAG $(0.625 \mu \mathrm{mol} / 1)$ or a combination of $0.625 \mu \mathrm{mol} / 1$ 17-AAG and $8 \mu \mathrm{mol} / 1$ salinomycin. Representative images of cell morphology are presented (magnification, $\mathrm{x} 100)$. The experiments were repeated in triplicate. 17-AAG, 17-allylamine-17-demathoxygeldanamycin.

morphology, cells were treated with salinomycin, 17-AAG, or salinomycin+17-AAG, and cell morphology was observed under an inverted microscope. As presented in Fig. 1, untreated SGC-7901 cells exhibited adherent and tight growth with polygon or fusiform shapes, with a plump cytoplasm and tight connections between cells. However, after a 48-h treatment with salinomycin or 17-AAG, cell volume decreased. The cell membrane and nuclear membrane began to break and shrink. Cells grew slowly with increased gaps, and connections disappeared. Furthermore, the higher the salinomycin concentration, the more significant and severe alterations in SGC-7901 cell morphology, with reduced cell numbers. When cells were treated with salinomycin and 17-AAG together, the cell number and volume were further reduced; the cell cytoplasm condensed, and nuclei were further enriched and broken compared with groups treated with salinomycin or 17-AAG alone. These results indicated that salinomycin may alter SGC-7901 cell morphology when used alone or combined with 17-AAG.

Salinomycin and 17-AAG inhibits SGC-7901 cell proliferation in vitro. To evaluate the effects of salinomycin and 17-AAG on SGC-7902 cell proliferation, an MTT assay was conducted. The results demonstrated salinomycin inhibited SGC-7901 cell proliferation significantly in a time-dependent manner (24, 48 and $72 \mathrm{~h})$ within a concentration range from 1 to $32 \mu \mathrm{mol} / 1$, when compared with the control group (Fig. 2A; $\mathrm{P}<0.01)$. Furthermore, the cell proliferation inhibitory effects in cells following salinomycin treatment with the indicated concentrations $(4,8$ and $16 \mu \mathrm{mol} / \mathrm{l})$ were significantly increased compared with the control, salinomycin and 17-AAG groups when combined with 17-AAG $(0.625 \mu \mathrm{mol} / \mathrm{l})$ for indicated time points $(24,48$ and 72 h; Fig. $2 \mathrm{~B}-\mathrm{F}$; $\mathrm{P}<0.05)$. The results indicated that salinomycin may inhibit SGC-7901 cell proliferation in vitro, and enhance cell sensitivity to 17-AAG.

Salionomycin and 17-AAG inhibition of SGC-7901 cell cycle. To determine the effects of salinomycin and 17-AAG on SGC-7901 cell cycle, flow cytometry was performed (Fig. 3). The results demonstrated that after a 48-h treatment with salinomycin $(4,8$ and $16 \mu \mathrm{mol} / \mathrm{l})$ or $0.625 \mu \mathrm{mol} / \mathrm{l} 17-\mathrm{AAG}$ alone (Fig. 3A and B; D-H), numbers of cells in G0/G1 phase were significantly decreased, whereas those in $\mathrm{S}$ phase were significantly increased compared with the control group $(\mathrm{P}<0.05)$. Additionally, when treated with $8 \mu \mathrm{mol} / 1$ salinomycin and $0.625 \mu \mathrm{mol} / 1$ 17-AAG, numbers of cells in $\mathrm{S}$ phase were significantly increased compared with the control, salinomycin and $17-\mathrm{AAG}$ groups (Fig. $3 \mathrm{C}$ and $\mathrm{H}$; $\mathrm{P}<0.05$ ). These results suggested that salinomycin and 17-AAG may arrest cells in $\mathrm{S}$ phase, and that salinomycin combined with $17-\mathrm{AAG}$ may enhance this effect on the cell cycle.

Salinomycin and 17-AAG induce SGC-7901 cell apoptotic morphology. To investigate the effects of salinomycin and 17-AAG on SGC-7901 cell apoptosis, PI and AO staining were performed and fluorescent microscope was used for detection (Fig. 4). As presented in Fig. 4A, cells in the control group grew well with uniform size, regular nuclei shapes, neat edges of nuclear membranes and regular chromatin distribution. Furthermore, cells exhibited typical red and green fluorescence signals after PI and AO staining, respectively (Fig. 4A). When treated with 17-AAG (Fig. 4B) or salinomycin (Fig. 4D-F) alone for $48 \mathrm{~h}$, cell morphology altered significantly, including slower growth, reduced cell numbers, 

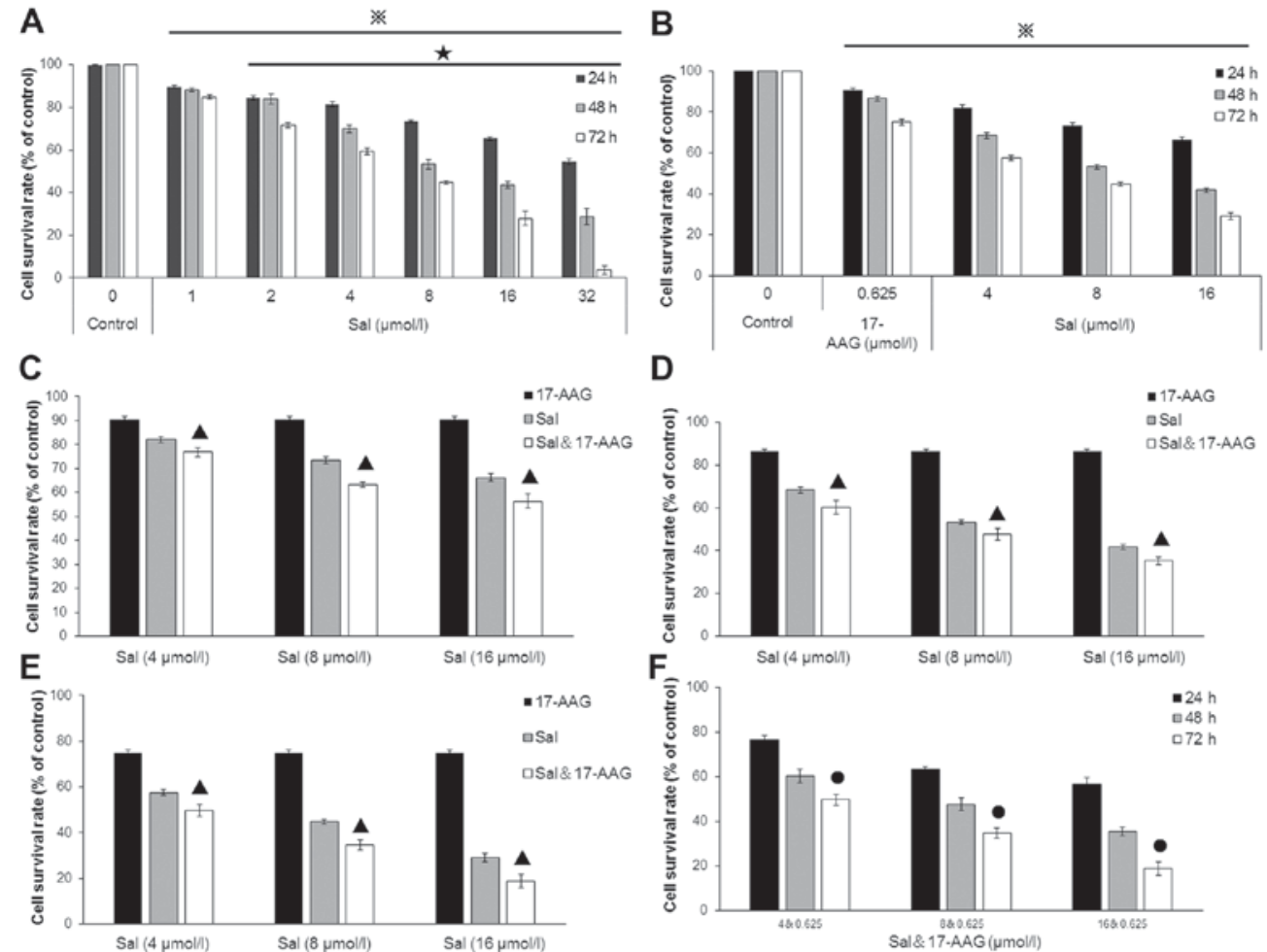

Figure 2. Survival rate of SGC-7901 cells treated with salinomycin and 17-AAG. To clarify the effects of salinomycin and 17-AAG on SGC-7901 cell proliferation, MTT was performed. Survival rates of cells treated with (A) salinomycin only, (B) $0.625 \mu \mathrm{mol} / 1$ 17-AAG or salinomycin, (C) $0.625 \mu \mathrm{mol} / 1$ 17-AAG and salinomycin alone, or combined for $24 \mathrm{~h}$, (D) $0.625 \mu \mathrm{mol} / 1$ 17-AAG and salinomycin alone, or combined for $48 \mathrm{~h}$, (E) $0.625 \mu \mathrm{mol} / 117-\mathrm{AAG}$ and salinomycin alone or in combination for $72 \mathrm{~h}$, (F) $0.625 \mu \mathrm{mol} / 1$ 17-AAG in combination with 4,8 and $16 \mu \mathrm{mol} / 1$ salinomycin for 24,48 and $72 \mathrm{~h}$. Data are expressed as the mean \pm standard deviation. $\mathrm{P}<0.05$ vs. control group for the same time point. ${ }^{\star} \mathrm{P}<0.05$ vs. previous salinomycin concentration. ${ }^{\bullet} \mathrm{P}<0.05$ vs. previous time point. ${ }^{\triangle} \mathrm{P}<0.05$ vs. group only treated with salinomycin or 17-AAG. The experiments were repeated in triplicate. 17-AAG, 17-allylamine-17-demathoxygeldanamycin.
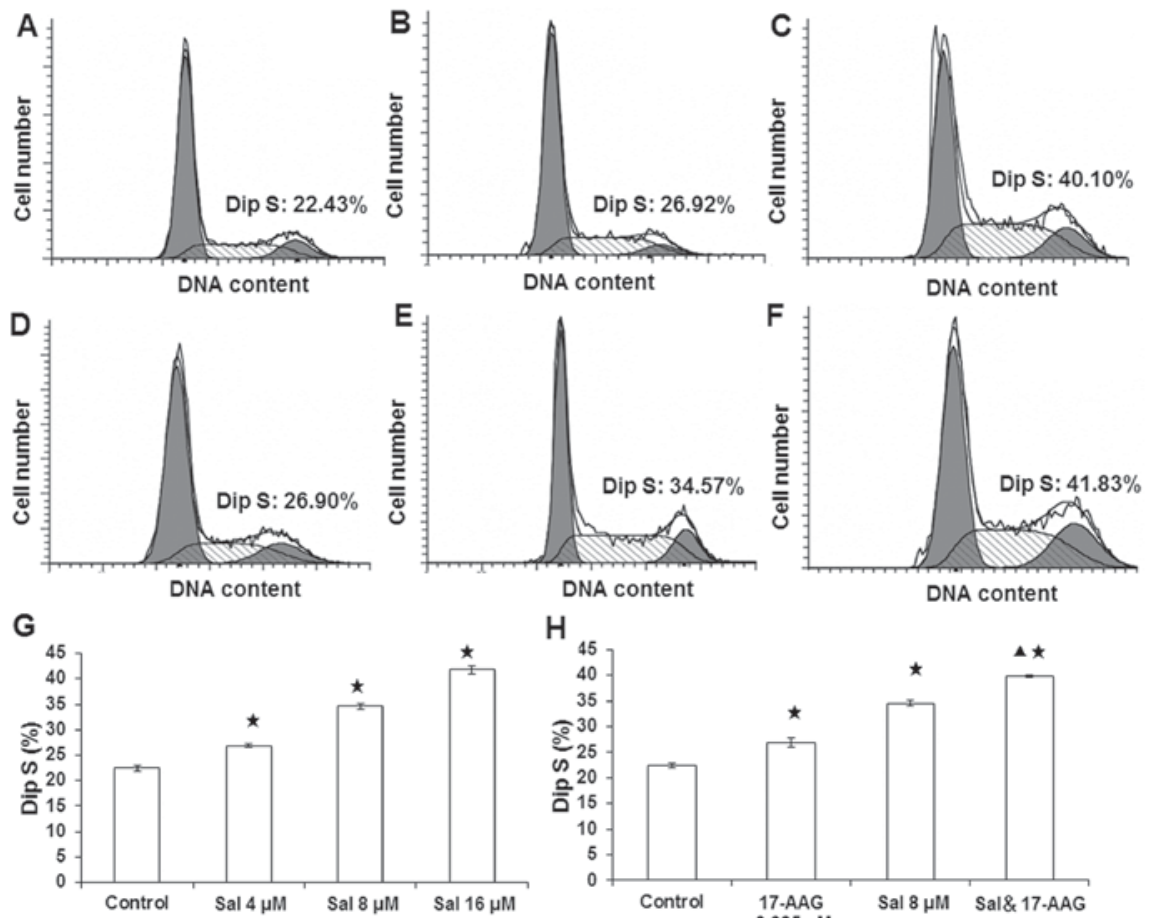

$\mathrm{H}$

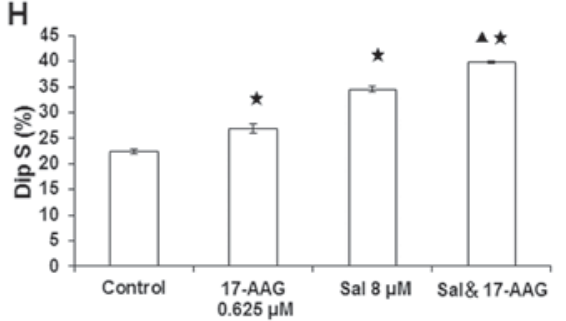

Figure 3. Salinomycin and 17-AAG blocks SGC-7901 cell cycle. Flow cytometry was conducted to detect the effects of salinomycin and 17-AAG on SGC-7901 cell cycle. (A) Control cells. Cells treated with (B) $0.625 \mu \mathrm{mol} / 1$ 17-AAG for $48 \mathrm{~h}$, (C) $0.625 \mu \mathrm{mol} / 1$ 17-AAG and $8 \mu \mathrm{mol} / 1 \mathrm{salinomycin}$ for $48 \mathrm{~h}$, (D) $4 \mu \mathrm{mol} / 1$ salinomycin for $48 \mathrm{~h}$, (E) $8 \mu \mathrm{mol} / 1$ salinomycin for $48 \mathrm{~h}$ and (F) $16 \mu \mathrm{mol} / 1$ salinomycin for $48 \mathrm{~h}$. (G) Percentage of cell in S phase in control cells or cells treated with salinomycin $(4,8$ and $16 \mu \mathrm{mol} / 1)$. (H) Percentage of cell in S phase in control cells or cells treated with salinomycin $(8 \mu \mathrm{mol} / 1), 17-\mathrm{AAG}(0.625 \mu \mathrm{mol} / 1)$ and salinomycin+17-AAG. Data are expressed as the mean \pm standard deviation of three independent experiments. ${ }^{\star} \mathrm{P}<0.05$ vs. control group. ${ }^{\boldsymbol{}} \mathrm{P}<0.05$ vs. groups treated with salinomycin or 17-AAG alone. Sal, salinomycin; 17-AAG, 17-allylamine-17-demathoxygeldanamycin. 

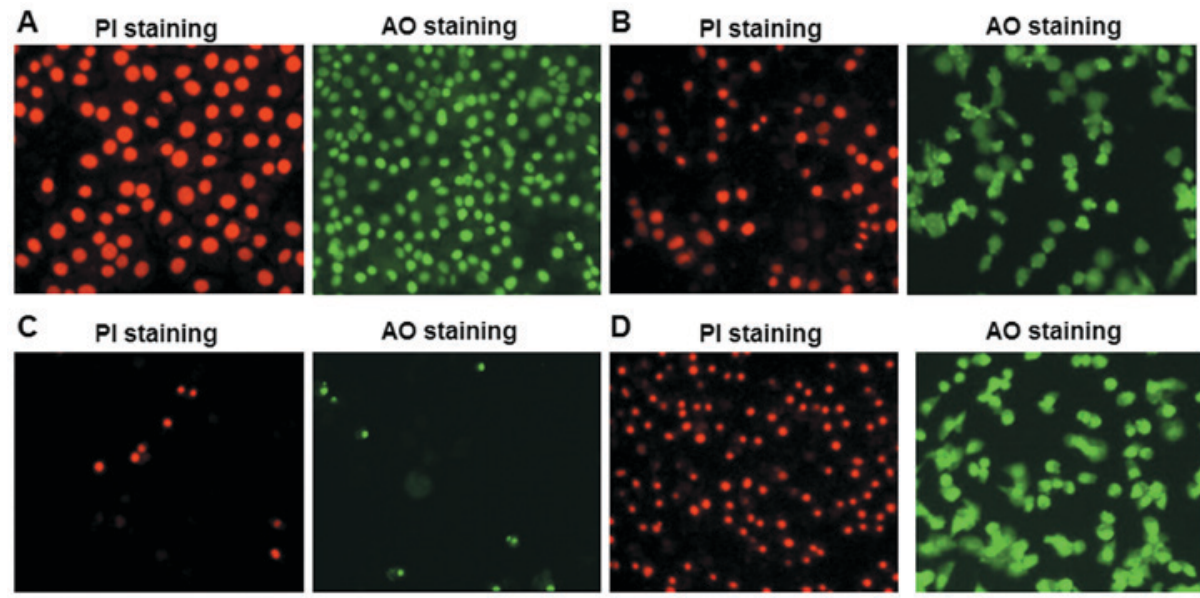

AO staining

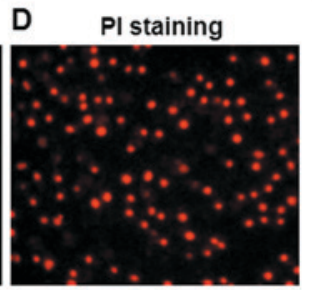

AO staining
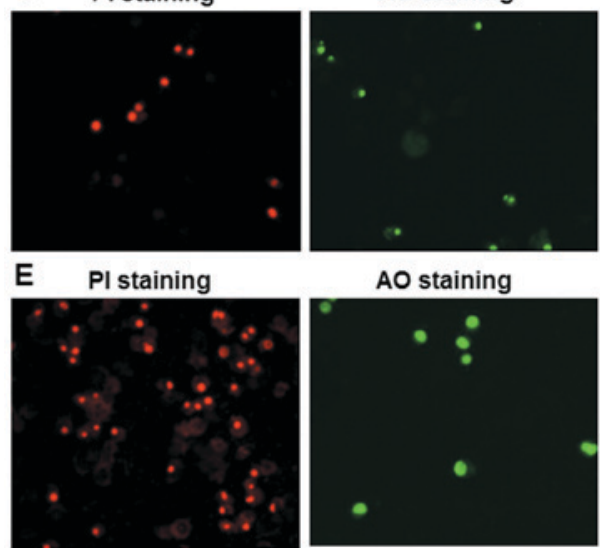

AO staining
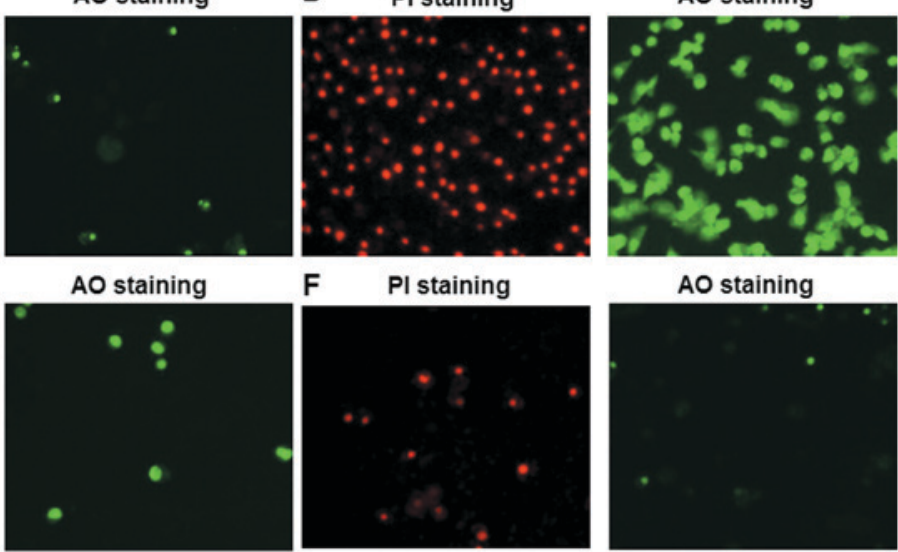

AO staining

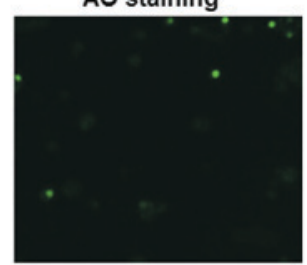

Figure 4. Salinomycin and 17-AAG induces apoptotic morphology in SGC-7901 cells. PI and AO staining were performed to detect apoptosis, and cell morphology was observed under an inverted microscope. PI staining is shown in red and AO staining is shown in green. Representative images of PI (red) and AO (green) staining in (A) control cells, (B) cells treated with $0.625 \mu \mathrm{mol} / 1$ 17-AAG only for $48 \mathrm{~h},(\mathrm{C})$ cells treated with both $0.625 \mu \mathrm{mol} / 1$ 17-AAG and $8 \mu \mathrm{mol} / 1$ salinomycin for $48 \mathrm{~h}$, (D) cells treated with $4 \mu \mathrm{mol} / 1$ salinomycin for $48 \mathrm{~h}$, (E) cells treated with $8 \mu \mathrm{mol} / 1 \mathrm{salinomycin}$ for $48 \mathrm{~h}$, and (F) cells treated with $16 \mu \mathrm{mol} / 1$ salinomycin for $48 \mathrm{~h}$. The experiments were repeated in triplicate. PI, propidium iodide; 17-AAG, 17-allylamine-17-demathoxygeldanamycin; AO, acridine orange

nuclei condensation, DNA enrichment near the nuclear membrane, apoptotic body formation, enhanced nuclear refraction and dense fluorescence, which were more obvious in groups treated with higher doses. Furthermore, when cells were treated with salinomycin and 17-AAG together for $48 \mathrm{~h}$, cell apoptotic morphology altered more clearly compared with groups treated with salinomycin or 17-AAG alone (Fig. 4C). These results demonstrated that salinomycin and 17-AAG may induce SGC-7901 cell apoptotic morphology, and that the apoptosis was more severe when salinomycin and 17-AAG were used together.

Salinomycin and 17-AAG promotes SGC-7901 cell apoptosis. To identify whether salinomycin and 17-AAG could promote cell apoptosis in SGC-7901 cells, flow cytometry was performed. As presented in Fig. 5, compared with the control group (Fig. 5A), 48-h treatment with $0.625 \mu \mathrm{mol} / 1$ 17-AAG (Fig. 5B) or 4, 8, $16 \mu \mathrm{mol} / 1$ salinomycin (Fig. 5D-G) significantly increased SGC-7901 cell apoptosis $(\mathrm{P}<0.05)$. Furthermore, the $48 \mathrm{~h}$ co-treatment of $0.625 \mu \mathrm{mol} / 1$ 17-AAG and $8 \mu \mathrm{mol} / 1$ salinomycin significantly promoted cell apoptosis compared with the control and drug treatment alone groups (Fig. 5C and $\mathrm{H} ; \mathrm{P}<0.05$ ). These results implied that both salinomycin and 17-AAG could promote cell apoptosis with a synergistic effect.

Salinomycin and 17-AAG activates the Fas/Fas-L signaling pathway while inhibiting the $N F-\kappa B$ pathway. To further elucidate the pro-apoptotic mechanism of salinomycin and 17-AAG, immunocytochemistry was conducted to detect the protein expression levels of NF- $\mathrm{KB}$ and Fas-L in SGC-7901 cells of each group; factors which serve important roles in tumorigenesis and pro-apoptosis, respectively.

Untreated cells incubated with PBS, in place of the primary antibody, served as the secondary antibody control (Fig. 6A). In untreated negative control cells, $\mathrm{NF}-\kappa \mathrm{B}$ expression was primarily identified in the nucleus and cytoplasm in control cells (Fig. 6B). In cells treated with $0.625 \mu \mathrm{mol} / 1$ 17-AAG (Fig. 6C) or salinomycin (4,8 and $16 \mu \mathrm{mol} / \mathrm{l}$; Fig. 6D-F, respectively), $\mathrm{NF}-\kappa \mathrm{B}$ expression was significantly decreased in both in the nucleus and cytoplasm. Furthermore, in cells treated with both $0.625 \mu \mathrm{mol} / 1$ 17-AAG and $8 \mu \mathrm{mol} / 1 \mathrm{sali}-$ nomycin (Fig. 6G), the decrease of $\mathrm{NF}-\kappa \mathrm{B}$ signal was more marked compared with the control, salinomycin and 17-AAG groups.

Fas-L expression was also detected by immunocytochemistry. No Fas-L expression was observed in the untreated secondary antibody control cells (Fig. 7A). Fas-L was expressed in the cytoplasm and membrane of untreated negative control cells (Fig. 7B). Fas-L expression was increased in the cytoplasm and membrane of cells treated with 17-AAG compared with control cells (Fig. 7C). In cells treated with both 17-AAG and salinomycin, increased Fas-L signals were observed both in the cytoplasm and nucleus (Fig. 7D). In cells treated with 4, 8 and $16 \mu \mathrm{mol} / 1$ salinomycin (Fig. 7E-G, respectively), Fas-L expression in the cytoplasm was increased, particularly in the $16 \mu \mathrm{mol} / 1$ salinomycin group (Fig. 7G), in which nuclear Fas-L signals were observed as well.

These results indicated that the pro-apoptotic effects of salinomycin and 17-AAG on SGC-7901 cells may be associated with activation of the Fas/Fas-1 signaling pathway, and inhibition of the $\mathrm{NF}-\kappa \mathrm{B}$ signaling pathway. 

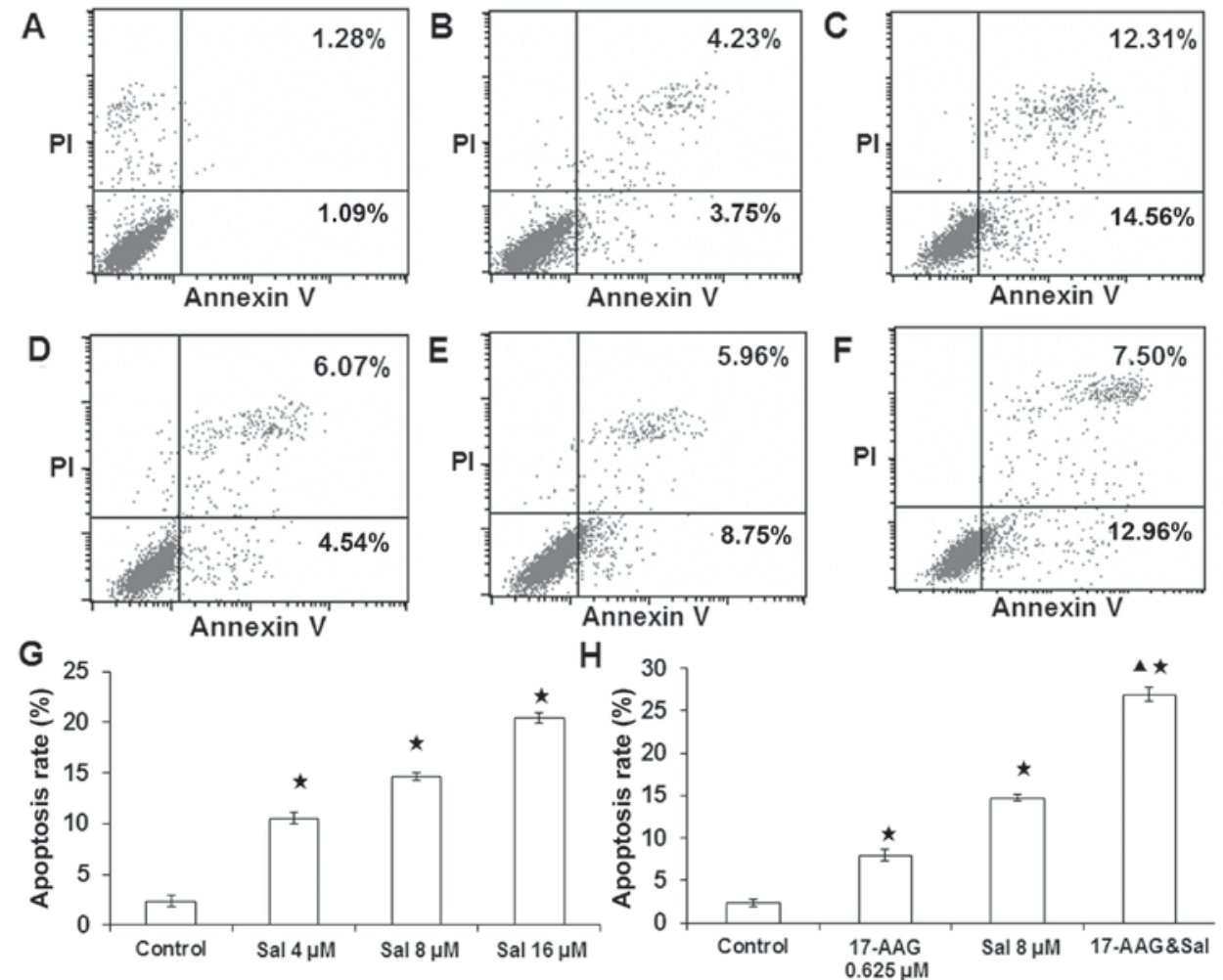

Figure 5. Salinomycin and 17-AAG induces SGC-7901 cell apoptosis. To verify the effects of salinomycin and 17-AAG on SGC-7901 cell apoptosis, flow cytometry was performed. Representative images of cell apoptosis in (A) control cells, (B) cells treated with $0.625 \mu \mathrm{mol} / 1$ 17-AAG for $48 \mathrm{~h}$, (C) cells treated with both $0.625 \mu \mathrm{mol} / 1$ 17-AAG and $8 \mu \mathrm{mol} / 1$ salinomycin for $48 \mathrm{~h}$, (D) cells treated with $4 \mu \mathrm{mol} / 1$ salinomycin for $48 \mathrm{~h}$, (E) cells treated with $8 \mu$ mol/l salinomycin for $48 \mathrm{~h}$ and (F) cells treated with $16 \mu \mathrm{mol} / 1$ salinomycin for $48 \mathrm{~h}$. (G) Percentage of apoptotic cells in cells treated with (G) salinomycin alone and (H) cells treated with salinomycin, 17-AAG and Sal+17-AAG. Data are presented as the mean \pm standard deviation of three independent experiments. ${ }^{\star} \mathrm{P}<0.05$ vs. control group. ${ }^{\mathbf{A}} \mathrm{P}<0.05$ vs. groups treated with salinomycin or 17-AAG alone. 17-AAG, 17-allylamine-17-demathoxygeldanamycin; Sal, salinomycin.
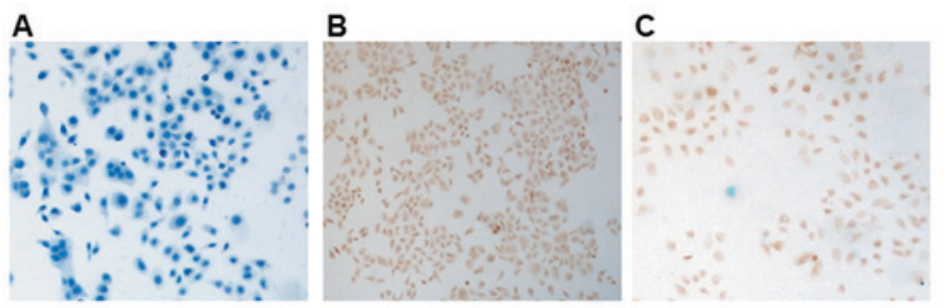

D

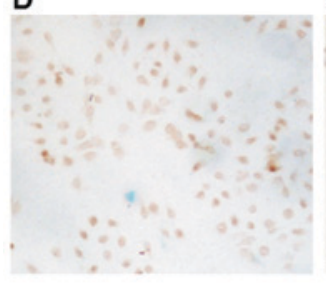

E

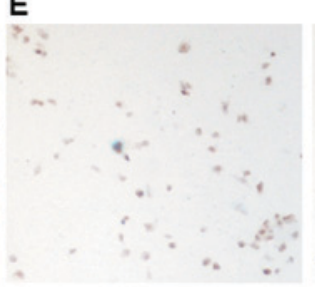

$\mathrm{F}$

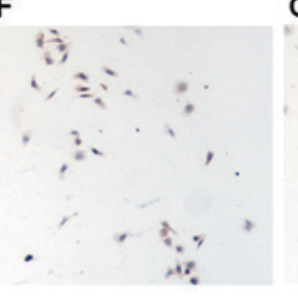

G

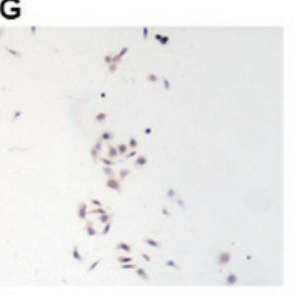

Figure 6. Salinomycin and 17-AAG reduces NF-кB protein expression in SGC-7901 cells. Representative immunocytochemistry images of NF- $\kappa$ B protein expression in the (A) secondary antibody control (untreated cells with PBS as primary antibody), (B) untreated negative control cells, (C) $0.625 \mu$ mol/1 $17-\mathrm{AAG}$, (D) both $0.625 \mu \mathrm{mol} / 1$ 17-AAG and $8 \mu \mathrm{mol} / 1$ salinomycin, (E) $4 \mu \mathrm{mol} / 1$ salinomycin, (F) $8 \mu \mathrm{mol} / 1$ salinomycin and (G) $16 \mu \mathrm{mol} / 1$ salinomycin treatment groups

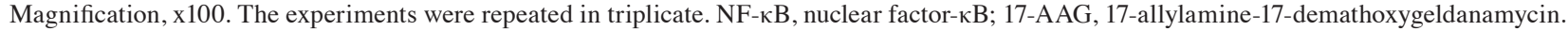

\section{Discussion}

Gastric cancer is one of the most common types of malignant tumor (24). As an ionophore type antibiotic, salinomycin serves an important role in inhibiting tumor cell proliferation (9,13-19). However, the strong neurotoxic effects of salinomycin have been previously reported $(20,25)$. 17-AAG is an inhibitor of HSP; its anti-tumor effect has already been widely accepted $(26,27)$, and it has fewer side effects $(21,22)$. The present study demonstrated that the combination of salinomycin and 17-AAG exhibited improved anti-tumor effects compared with treatment of one alone. 
A

B

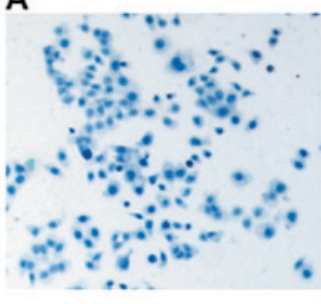

B

C $\ldots$ D
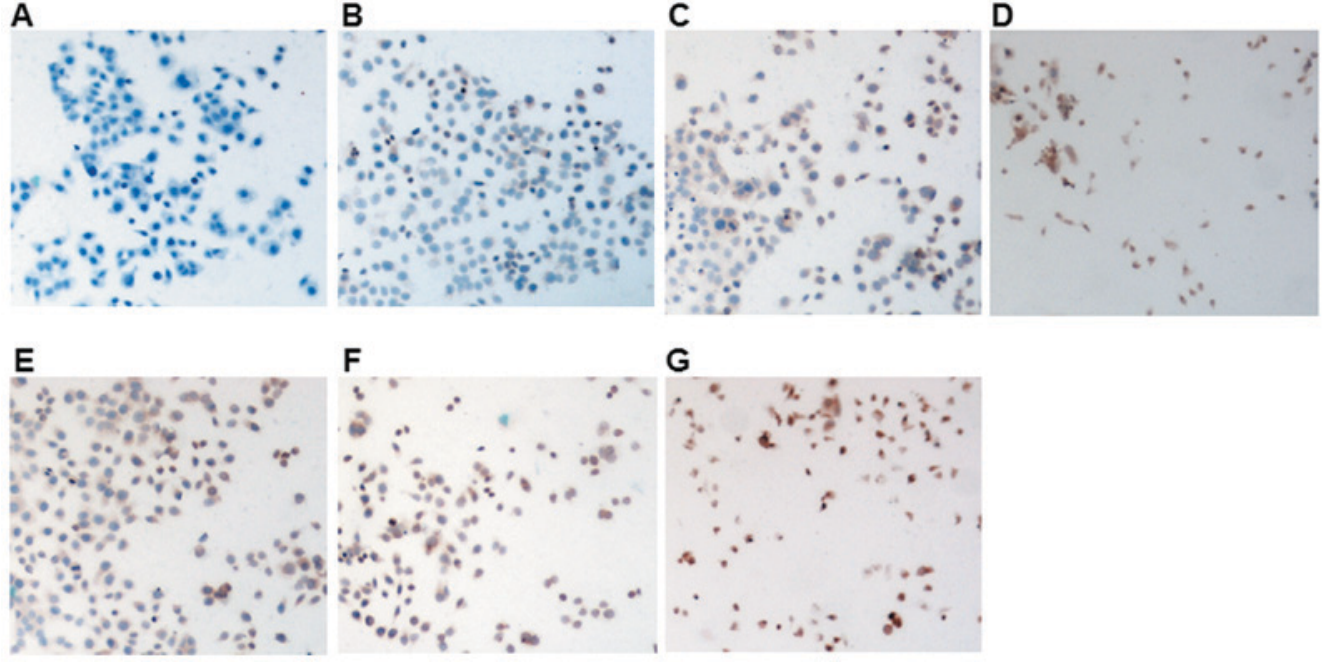

Figure 7. Combination of salinomycin and 17-AAG increased Fas-L protein expression in SGC-7901 cells. Representative immunocytochemistry images of Fas-L protein expression in the (A) secondary antibody control (untreated cells with PBS as primary antibody), (B) untreated negative control cells, (C) $0.625 \mu \mathrm{mol} / 1$ 17-AAG, (D) both $0.625 \mu \mathrm{mol} / 1$ 17-AAG and $8 \mu \mathrm{mol} / 1$ salinomycin, (E) $4 \mu \mathrm{mol} / 1 \mathrm{salinomycin},(\mathrm{F}) 8 \mu \mathrm{mol} / 1 \mathrm{salinomycin}$ and (G) $16 \mu \mathrm{mol} / 1$ salinomycin treatment groups. Magnification, x100. The experiments were repeated in triplicate. 17-AAG, 17-allylamine-17-demathoxygeldanamycin; Fas-L, Fas-ligand.

An et al (28) reported that salinomycin inhibits mammary stem cell proliferation via an apoptosis-independent pathway. Zhi et al (29) additionally demonstrated that salinomycin could selectively inhibit gastric cancer cells. The present study revealed that salinomycin inhibits SGC-7901 gastric cancer cell proliferation in a dose- and time-dependent manner within a certain concentration range, consistent with the previously mentioned studies. These results imply that salinomycin may induce apoptosis of gastric cancer cells. The present study additionally demonstrated that combination with 17-AAG could enhance the cell proliferation inhibitory effects of salinomycin significantly, and the sensitivity of SGC-7901 cells to 17-AAG. Notably, single and combined treatment of salinomycin and 17-AAG altered SGC-7901 cell morphology, particularly combined treatment. PI and $\mathrm{AO}$ fluorescent staining and flow cytometry results indicated that the apoptotic rate of cells treated with both salinomycin and 17-AAG together was significantly increased compared with cells treated with salinomycin or 17-AAG alone, implying that combination of these two agents could induce gastric cancer cell apoptosis synergistically. These results were consistent with a study by Liu et al (30), where salinomycin was identified to promote Jurkat cell apoptosis when used alone or combined with Vincristin. According to flow cytometry detection, salinomycin alone altered the cell cycle and prolonged $S$ phase, and this effect was stronger when salinomycin was used together with 17-AAG. The potential mechanism may be the interference of DNA synthesis and replication. However, Zhang et al (31) demonstrated that salinomycin arrested the cell cycle of nasopharyngeal carcinoma cells at G2/M phase, while Parajuli et al (32) revealed that salinomycin could arrest cisplatin-resistant ovarian cancer cells at G1 phase. Therefore, the effect of salinomycin on cancer cell cycle requires further investigation.

The present study further investigated the mechanism underlying the pro-apoptotic effect of salinomycin and 17-AAG. NF-KB is an important nuclear transcription factor with numerous biological activities, including inflammation, viral infection, tumorigenesis and cancer progression $(33,34)$.
Fas/Fas-L are cell membrane molecules, and serve as pro-apoptotic factors in the death receptor signaling pathway $(35,36)$. The specific binding of Fas/Fas-L may initiate pro-apoptitic signaling $(37,38)$. Due to the important roles of $\mathrm{NF}-\kappa \mathrm{B}$ and Fas in apoptosis (39-43), it was hypothesized that the anti-tumor effects of salinomyin may be associated with these proteins. Parajuli et al (44) demonstrated that salinomycin could inhibit nuclear transport of NF- $\kappa$ B. Consistently, immunocytochemistry results of the present study revealed that salinomycin downregulated $\mathrm{NF}-\kappa \mathrm{B}$ protein expression, whereas upregulated Fas-L protein expression in SGC-7901 cells. Therefore, the pro-apoptotic effects of salinomycin and 17-AAG may be associated with inhibition of the NF- $\kappa \mathrm{B}$ signaling pathway, and activation of the Fas/Fas-L signaling pathway.

In conclusion, the individual use of salinomycin and combined use with 17-AAG may significantly inhibit SGC-7901 gastric cancer cell proliferation and induce cell apoptosis. The potential mechanisms may be associated with upregulation of Fas-L and downregulation of NF- $\kappa$ B. These results provide a basis for the potential use of salinomycin in gastric cancer treatment.

\section{Acknowledgements}

The present study was supported by the National Natural Science Fund Grant (grant no. 81470140) and the Science and Technology Project of Education Department of Shanxi Province (grant no. 2013JK0783).

\section{References}

1. Jemal A, Bray F, Center MM, Ferlay J, Ward E and Forman D: Global cancer statistics. CA Cancer J Clin 61: 69-90, 2011.

2. Chen WQ, Zeng HM, Zheng RS, Zhang SW and He J: Cancer incidence and mortality in China, 2007. Chin J Cancer Res 24: 1-8, 2012

3. Chen W, Zhang R, Zhang S, Zhao P, Li G, Wu L and He J: Report of incidence and mortality in China cancer registries, 2009. Chin J Cancer Res 25: 10-21, 2013. 
4. Chen WQ, Zheng RS, Zeng HM, Zhang SW, Zhao P and Hao J: Trend analysis and projection of cancer incidence in China between 1989 and 2008. Zhonghua Zhong Liu Za Zhi 34: 517-524, 2012 (In Chinese).

5. Sjödahl K, Lu Y, Nilsen TI, Ye W, Hveem K, Vatten L and Lagergren J: Smoking and alcohol drinking in relation to risk of grastric cancer: A population-based, prospective cohort study. Int J Cancer 120: 128-132, 2007.

6. Niccolai E, Taddei A, Prisco D and Amedei A: Gastric cancer and the epoch of immunotherapy approaches. World J Gastroenterol 21: 5778-5793, 2015.

7. Xu W, Yang Z and Lu N: Molecular targeted therapy for the treatment of gastric cancer. J Exp Clin Cancer Res 35: 1, 2016.

8. Miyazaki Y, Shibuya M, Sugawara H, Kawaguchi O and Hirsoe C: Salinomycin, a new polyether antibiotic. J Antibiot (Tokyo) 27: 814-821, 1974.

9. Daugschies A, Gässlein U and Rommel M: Comparative efficacy of anticoccidials under the conditions of commercial broiler production and in battery trials. Vet Parasitol 76: 163-171, 1998.

10. Danforth HD, Ruff MD, Reid WM and Miller RL: Anticoccidial activity of salinomycin in battery raised broiler chickens. Poult Sci 56: 926-932, 1977.

11. Mahmoudi N, de Julián-Ortiz JV, Ciceron L, Gálvez J, Mazier D, Danis M, Derouin F and García-Domenech R: Identification of new antimalarial drugs by linear discriminant analysis and topological virtual screening. J Antimicrob Chemother 57: 489-497, 2006.

12. Gupta PB, Onder TT, Jiang G, Tao K, Kuperwasser C, Weinberg RA and Lander ES: Identification of selective inhibitors of cancer stem cells by high-throughput screening. Cell 138: 645-659, 2009.

13. Naujokat C, Fuchs D and Opelz G: Salinomycin in cancer: A new mission for an old agent. Mol Med Report 3: 555-559, 2010.

14. Kopp F, Hermawan A, Oak PS, Ulaganathan VK, Herrmann A, Elnikhely N, Thakur C, Xiao Z, Knyazev P, Ataseven B, et al: Sequential salinomycin treatment results in resistance formation through clonal selection of epithelial-like tumor cells. Trans Oncol 7: 702-711, 2014.

15. Kim JH, Chae M, Kim WK, Kim YJ, Kang HS, Kim HS and Yoon S: Salinomycin sensitizes cancer cells to the effects of doxorubicin and etoposide treatment by increasing DNA damage and reducing p21 protein. Br J Pharmacol 162: 773-784, 2011.

16. Xiao Z, Sperl B, Ullrich A and Knyazev P: Metformin and salinomycin as the best combination for the eradication of NSCLC monolayer cells and their alveospheres (cancer stem cells) irrespective of EGFR, KRAS, EML4/ALK and LKB1 status. Oncotarget 5: 12877-12890, 2014.

17. Antoszczak M, Popiel K, Stefańska J, Wietrzyk J, Maj E, Janczak J, Michalska G, Brzezinski B and Huczyński A Synthesis, cytotoxicity and antibacterial activity of new esters of polyether antibiotic-salinomycin. Eur J Med Chem 76: 435-444, 2014.

18. Kopp F, Hermawan A, Oak PS, Herrmann A, Wagner E and Roidl A: Salinomycin treatment reduces metastatic tumor burden by hampering cancer cell migration. Mol Cancer 13: 16, 2014.

19. Huczynski A: Salinomycin: A new cancer drug candidate. Chem Biol Drug Des 79: 235-238, 2012.

20. Boehmerle W, Muenzfeld H, Springer A, Huehnchen P and Endres M: Specific targeting of neurotoxic side effects and pharmacological profile of the novel cancer stem cell drug salinomycin in mice. J Mol Med (Berl) 92: 889-900, 2014.

21. Schulte TW and Neckers LM: The benzoquinone ansamycin 17-allylamino-17-demethoxygeldanamycin binds to Hsp90 and shares important biologic activities with geldanamycin. Cancer Chemother Pharmacol 42: 273-279, 1998 .

22. Schnur RC, Corman ML, Gallaschun RJ, Cooper BA, Dee MF, Doty JL, Muzzi ML, Moyer JD, DiOrio CI, Barbacci EG, et al: Inhibition of the oncogene product p185erbB-2 in vitro and in vivo by geldanamycin and dihydrogeldanamycin derivatives. J Med Chem 38: 3806-3812, 1995.

23. Chen S, Chen X, Li Y, Yang S, Mo X, Zhang F, Mo K and Ding Y: Inhibitory effect of 17-AAG combined with paclitaxel on proliferation of esophageal squamous cell carcinoma Eca-109 cells in vitro. Nan Fang Yi Ke Da Xue Xue Bao 35: 844-847, 2015 (In Chinese).

24. Wu HH,Lin WC and Tsai KW: Advances in molecular biomarkers for gastric cancer: miRNAs as emerging novel cancer markers. Expert Rev Mol Med 16: e1, 2014
25. Song SP, Zhang XG, Wang M, et al: Changes and significance of serum creatine kinase and isoenzymes in salinomycin poisoning patients. Zhong Guo Wei Sheng Jian Yan Za Zhi 21: 28-29, 2011 (in Chinese)

26. Kim SH, Kang JG, Kim CS, Ihm SH, Choi MG, Yoo HJ and Lee SJ: 17-Allylamino-17-demethoxygeldanamycin and Herbimycin A induce cell death by modulating $\beta$-catenin and PI3K/AKT signaling in FRO anaplastic thyroid carcinoma cells. Anticancer Res 35: 5453-5460, 2015.

27. Xu Y, Zhu Q, Chen D, Shen Z, Wang W, Ning G and Zhu Y: The HSP90 inhibitor 17-AAG exhibits potent antitumor activity for pheochromocytoma in a xenograft model. Tumour Biol 36: 5103-5108, 2015

28. An H, Kim JY, Lee N, Cho Y, Oh E and Seo JH: Salinomycin possesses anti-tumor activity and inhibits breast cancer stem-like cells via an apoptosis-independent pathway. Biochem Biophys Res Commun 466: 696-703, 2015.

29. Zhi QM, Chen XH, Ji J, Zhang JN, Li JF, Cai Q, Liu BY, Gu QL, Zhu ZG and Yu YY: Salinomycin can effectively kill ALDH(high) stem-like cells on gastric cancer. Biomed Pharmacother 65: 509-515, 2011

30. Liu PP, Zhu JC, Liu GX, Shui CX and Li XM: Salinomycin enhances the apoptosis of T-cell acute lymphoblastic leukemia cell line jurkat cells induced by vincristine. Zhongguo Shi Yan Xue Ye Xue Za Zhi 23: 653-657, 2015 (In Chinese).

31. Zhang Y, Zuo Y, Guan Z, Lu W, Xu Z, Zhang H, Yang Y, Yang M, Zhu $\mathrm{H}$ and Chen X: Salinomycin radiosensitizes human nasopharyngeal carcinoma cell line CNE-2 to radiation. Tumor Biol 37: 305-311, 2016

32. Parajuli B, Lee HG, Kwon SH, Cha SD, Shin SJ, Lee GH, Bae I and $\mathrm{Cho} \mathrm{CH}$ : Salinomycin inhibits $\mathrm{Akt} / \mathrm{NF}-\kappa \mathrm{B}$ and induces apoptosis in cisplatin resistant ovarian cancer cells. Cancer Epidemiol 37: 512-517, 2013.

33. Cai Z, Tchou-Wong KM and Rom WN: NF-kappaB in lung tumorigenesis. Cancers (Basel) 3: 4258-4268, 2011.

34. Hayden MS and Ghosh S: Shared principles in NF-kappaB signaling. Cell 132: 344-362, 2008.

35. Wu GZ, Pan CX, Jiang D, Zhang Q, Li Y and Zheng SY: Clinicopathological significance of Fas and Fas ligand expressions in esophageal cancer. Am J Cancer Res 5: 2865-2871, 2015

36. Liu W, Xu C, Zhao H, Xia P, Song R, Gu J, Liu X, Bian J, Yuan Y and Liu Z: Osteoprotegerin induces apoptosis of osteoclasts and osteoclast precursor cells via the fas/fas ligand pathway. PLoS One 10: e0142519, 2015

37. Deng Y, Feng P, Chen D, et al: Effects of Fas and Fas-L in cell apoptosis. Guo Wai Yi Xue Mian Yi Xue Fen Ce 4: 213-216, 1997 (in Chinese).

38. Wang Y, Wang C, Jiang C, Zeng $\mathrm{H}$ and He X: Novel mechanism of harmaline on inducing $\mathrm{G} 2 / \mathrm{M}$ cell cycle arrest and apoptosis by up-regulating Fas/FasL in SGC-7901 cells. Sci Rep 5: 18613, 2015.

39. Kong FC, Zhang JQ, Zeng C, Chen WL, Ren WX, Yan GX, Wang HX, Li QB and Chen ZC: Inhibitory effects of parthenolide on the activity of NF- $\mathrm{KB}$ in multiple myeloma via targeting TRAF6. J Huazhong Univ Sci Technolog Med Sci 35: 343-349, 2015.

40. Diab S, Fidanzi C, Léger DY, Ghezali L, Millot M, Martin F, Azar R, Esseily F, Saab A, Sol V, et al: Berberis libanotica extract targets $\mathrm{NF}-\kappa \mathrm{B} / \mathrm{COX}-2$, PI3K/Akt and mitochondrial/caspase signalling to induce human erythroleukemia cell apoptosis. Int J Oncol 47: 220-230, 2015.

41. Gmeiner WH, Jennings-Gee J, Stuart $\mathrm{CH}$ and Pardee TS: Thymineless death in F10-treated AML cells occurs via lipid raft depletion and Fas/FasL co-localization in the plasma membrane with activation of the extrinsic apoptotic pathway. Leuk Res 39: 229-235, 2015.

42. Liu W, Lin YT, Yan XL, Ding YL, Wu YL, Chen WN and Lin X: Hepatitis B virus core protein inhibits Fas-mediated apoptosis of hepatoma cells via regulation of $\mathrm{mFas} / \mathrm{FasL}$ and $\mathrm{sFas}$ expression. FASEB J 29: 1113-1123, 2015.

43. Li L, Yao YC, Fang SH, Ma CQ, Cen Y, Xu ZM, Dai ZY, Li C, Li S, Zhang T, et al: Pigment epithelial-derived factor (PEDF)-triggered lung cancer cell apoptosis relies on p53 protein-driven Fas ligand (Fas-L) up-regulation and Fas protein cell surface translocation. J Biol Chem 289: 30785-30799, 2014.

44. Parajuli B, Shin SJ, Kwon SH, Cha SD, Chung R, Park WJ, Lee HG and Cho CH: Salinomycin induces apoptosis via death receptor-5 up-regulation in cisplatin-resistant ovarian cancer cells. Anticancer Res 33: 1457-1462, 2013. 